Article

\title{
Taurine Bromamine: Reactivity of an Endogenous and Exogenous Anti-Inflammatory and Antimicrobial Amino Acid Derivative
}

\author{
Luiza De Carvalho Bertozo ${ }^{1}$, Nelson Henrique Morgon ${ }^{2}$, Aguinaldo Robinson De Souza ${ }^{1}$ \\ and Valdecir Farias Ximenes ${ }^{1, *}$ \\ 1 Department of Chemistry, Faculty of Sciences, São Paulo State University (UNESP), Bauru 17033-360, Brazil; \\ luiza_bertozo@yahoo.com.br (L.D.C.B.); arobinso@fc.unesp.br (A.R.D.S.) \\ 2 Department of Chemistry, Institute of Chemistry, Campinas State University (UNICAMP), \\ Campinas 13083-861, Brazil; nhmorgon@gmail.commailto \\ * Correspondence: vfximenes@fc.unesp.br; Tel.: +55-014-3103-6088
}

Academic Editor: Jürg Bähler

Received: 27 March 2016; Accepted: 13 April 2016; Published: 21 April 2016

\begin{abstract}
Taurine bromamine (Tau-NHBr) is produced by the reaction between hypobromous acid $(\mathrm{HOBr})$ and the amino acid taurine. There are increasing number of applications of Tau-NHBr as an anti-inflammatory and microbicidal drug for topical usage. Here, we performed a comprehensive study of the chemical reactivity of Tau-NHBr with endogenous and non-endogenous compounds. Tau-NHBr reactivity was compared with $\mathrm{HOBr}$, hypochlorous acid $(\mathrm{HOCl})$ and taurine chloramine (Tau-NHCl). The second-order rate constants $\left(k_{2}\right)$ for the reactions between Tau-NHBr and tryptophan $\left(7.7 \times 10^{2} \mathrm{M}^{-1} \mathrm{~s}^{-1}\right)$, melatonin $\left(7.3 \times 10^{3} \mathrm{M}^{-1} \mathrm{~s}^{-1}\right)$, serotonin $\left(2.9 \times 10^{3} \mathrm{M}^{-1} \mathrm{~s}^{-1}\right)$, dansylglycine $\left(9.5 \times 10^{1} \mathrm{M}^{-1} \mathrm{~s}^{-1}\right)$, tetramethylbenzidine $\left(6.4 \times 10^{2} \mathrm{M}^{-1} \mathrm{~s}^{-1}\right)$ and $\mathrm{H}_{2} \mathrm{O}_{2}\left(3.9 \times \mathrm{M}^{-1} \mathrm{~s}^{-1}\right)$ were obtained. Tau-NHBr demonstrated the following selectivity regarding its reactivity with free amino acids: tryptophan $>$ cysteine $\sim$ methionine $>$ tyrosine. The reactivity of Tau- $\mathrm{NHBr}$ was strongly affected by the $\mathrm{pH}$ of the medium (for instance with dansylglycine: $\mathrm{pH} 5.0,1.1 \times 10^{4} \mathrm{M}^{-1} \mathrm{~s}^{-1}, \mathrm{pH} 7.0$, $9.5 \times 10 \mathrm{M}^{-1} \mathrm{~s}^{-1}$ and $\mathrm{pH} 9.0,1.7 \times 10 \mathrm{M}^{-1} \mathrm{~s}^{-1}$ ), a property that is related to the formation of the dibromamine form at acidic $\mathrm{pH}\left(\mathrm{Tau}-\mathrm{NBr}_{2}\right)$. The formation of singlet oxygen was observed in the reaction between Tau-NHBr and $\mathrm{H}_{2} \mathrm{O}_{2}$. Tau-NHBr was also able to react with linoleic acid, but with low efficiency compared with $\mathrm{HOBr}$ and $\mathrm{HOCl}$. Compared with $\mathrm{HOBr}$, Tau-NHBr was not able to react with nucleosides. In conclusion, the following reactivity sequence was established: $\mathrm{HOBr}>$ $\mathrm{HOCl}>\mathrm{Tau}-\mathrm{NHBr}>\mathrm{Tau}-\mathrm{NHCl}$. These findings can be very helpful for researchers interested in biological applications of taurine haloamines.
\end{abstract}

Keywords: taurine bromamine; tryptophan; melatonin; serotonin; singlet oxygen; nucleosides

\section{Introduction}

Hypochlorous acid $(\mathrm{HOCl})$ and hypobromous acid $(\mathrm{HOBr})$ are microbicidal agents produced when the white blood cells, neutrophils and eosinophils, respectively, are challenged by stimuli like bacteria and fungi [1]. Eosinophils, in particular, are associated with the host defense against parasitic helminth infections and asthma exacerbation [2,3]. These halogenating and oxidizing agents also play an important role in tissue damage associated with chronic inflammatory diseases [4,5]. For instance, eosinophilia, a characteristic of asthmatic subjects [6] has been associated with an increased level of 3-bromotyrosine, a biomarker of the damaging effects of $\mathrm{HOBr}$ [7].

The formation of these oxidants is due to the large amount of the enzymes myeloperoxidase (MPO) and eosinophil peroxidase (EPO) in these cells, which promote the catalytic oxidation of chloride $\left(\mathrm{Cl}^{-}\right)$and bromide $\left(\mathrm{Br}^{-}\right)$to $\mathrm{HOCl}$ and $\mathrm{HOBr}$, respectively $[8,9]$. The catalytic mechanism involves the 
transient production of the redox active compounds, named compound I (MPO-I and EPO-I), which are two electron oxidized compared with the native enzyme. An important difference between MPO-I and EPO-I is their standard reduction potential [10]. Thus, while MPO-I (1.16 V) is able to oxidize efficiently both $\mathrm{Cl}^{-}$and $\mathrm{Br}^{-}$[11]; EPO-I (1.09 V) shows a large preference for $\mathrm{Br}^{-}$[12]. This chemical feature, the higher plasma level of $\mathrm{Cl}^{-}(\sim 100 \mathrm{mM})$ compared with $\mathrm{Br}^{-}(\sim 100 \mu \mathrm{M})$, and the higher oxidant capacity of $\mathrm{HOCl}(1.28 \mathrm{~V})$ compared with $\mathrm{HOBr}(1.13 \mathrm{~V})$ [13], could suggest that the biological effect of $\mathrm{HOBr}$ would be irrelevant compared with $\mathrm{HOCl}$. However, this does not seem to be the case, since there is significant evidence that $\mathrm{HOBr}$ is more reactive with several biomolecules compared to $\mathrm{HOCl}[14,15]$. This phenomenon is the consequence of the higher electrophilicity of HOBr compared to $\mathrm{HOCl}[16]$.

Taurine bromamine (Tau-NHBr) is a chemical produced by the reaction between $\mathrm{HOBr}$ and the non-essential amino acid taurine. Yazdanbakhsh et al. provided the first application of Tau- $\mathrm{NHBr}$ and proposed its endogenous formation [17]. These authors found that stimulated eosinophils could be a source of Tau-NHBr, since these cells may produce $\mathrm{HOBr}$, and taurine is abundantly present in leukocytes. It is interesting to note that this finding took place just one year after the discovery that eosinophils could produce and release $\mathrm{HOBr}$ [18].

Currently, Tau-NHBr is used as an anti-inflammatory and a topical antimicrobial drug. Some examples of its applications are its use as a therapeutic agent for the treatment of acne vulgares [19,20]; treatment of biofilm-associated infections on dental surfaces caused by Pseudomonas aeruginosa [21,22]; microbicidal activity against Escherichia coli and Staphylococcus aureus at insensitive body regions with low organic matter [23]; inhibition of the production of inflammatory mediators, such as prostaglandin E2 (PGE2), nitric oxide (NO) and pro-inflammatory cytokines [24]; and inhibition of degradation of TNF- $\alpha$-induced Nuclear Factor-kappaB activation in Jurkat cells and myeloid-committed eosinophils [25]. The equivalent chlorinated haloamine is taurine chloramine (Tau- $\mathrm{NHCl}$, which is the reaction product of the interaction between taurine and $\mathrm{HOCl}$. Tau-NHCl is produced by activated neutrophils and released at inflammatory sites, inhibiting the production of inflammatory mediators [26]. An important chemical feature of Tau-NHCl, which makes this compound so interesting and extensively studied, is its mild oxidant capacity compared to its precursor $\mathrm{HOCl}$. Thus, Tau-NHCl is able to oxidize selectively sulfhydryl residues in proteins [27], and to act as an endogenous antioxidant [28]. These aspects might be involved in the signaling pathways susceptible to Tau-NHCl $[29,30]$. There are also a large number of applications for Tau- $\mathrm{NHCl}$ as a topical anti-inflammatory and anti-infective drug [31].

In contrast to Tau-NHCl, for which the chemical properties have been intensively studied [32], much less is known about Tau-NHBr. This was our motivation for undertaking this study. Here, the reactivity of Tau-NHBr was evaluated and compared with $\mathrm{HOBr}, \mathrm{HOCl}$ and Tau-NHCl, using several endogenous and non-endogenous chemicals. Using fast kinetic techniques, it was possible to measure the bimolecular rate constants of these reactions. We believe that this chemical data will be helpful for those interested in the application of this interesting compound.

\section{Results and Discussion}

\subsection{Preparation and Stability of Tau-NHBr}

Tau-NHBr can be prepared by reacting HOBr with taurine (Equation 1). However, it exists in equilibrium with its dibromamine form $\left(\mathrm{Tau}-\mathrm{NBr}_{2}\right)$ and, as has been demonstrated by Thomas et al., pure Tau-NHBr is only obtained using a large excess of taurine. In our studies, we usually prepare stock solutions of Tau-NHBr by reacting $5 \mathrm{mM}$ HOBr with $500 \mathrm{mM}$ taurine in $50 \mathrm{mM}$ phosphate buffer, $\mathrm{pH} 7.0$, i.e., a 100-fold excess of taurine. This solution was very stable when stored in the refrigerator and lost less than $20 \%$ of its initial concentration after five weeks [33].

$$
\begin{aligned}
& \mathrm{HO}_{3} \mathrm{SCH}_{2} \mathrm{CH}_{2} \mathrm{NH}_{2}+\mathrm{HOBr} \rightarrow \mathrm{HO}_{3} \mathrm{SCH}_{2} \mathrm{CH}_{2} \mathrm{NHBr} \\
& \text { (Taurine) ( } \mathrm{Tau}-\mathrm{NHBr}) \text {, }
\end{aligned}
$$




\subsection{Reactivity with Tryptophan}

Aiming to obtain a comprehensive knowledge of the chemical reactivity of Tau-NHBr, we used endogenous and non-endogenous compounds as potential targets. The first target was tryptophan, whose reactivity with $\mathrm{HOCl}$ and $\mathrm{HOBr}$ has been described [34,35]. Figure 1a shows the time-dependent fluorescence decay of tryptophan by the addition of Tau-NHBr. In these experiments, the concentration of tryptophan was kept constant at $25 \mu \mathrm{M}$ and the concentration of Tau-NHBr was varied from 100 to $500 \mu \mathrm{M}$. From this pseudo-first-order experimental condition, the apparent second-order rate constant $\left(k_{2}\right)$ was calculated $\left(7.7 \times 10^{2} \mathrm{M}^{-1} \mathrm{~s}^{-1}\right.$, Figure $\left.1 \mathrm{~b}\right)$. To gain insight into the significance of this value, it was compared with those obtained using $\mathrm{HOBr}, \mathrm{HOCl}$ and $\mathrm{Tau}-\mathrm{NHCl}$. Figure 1a shows that, whereas $150 \mu \mathrm{M}$ Tau-NHBr provoked the tryptophan fluorescence decay in about $20 \mathrm{~s}, \mathrm{HOBr}$ caused the same effect in less than $0.02 \mathrm{~s}$ (Figure 1c). Unfortunately, this reaction was too fast to determine $k_{2}$; however, its higher reactivity compared to Tau- $\mathrm{NHBr}$ was evident. Regarding $\mathrm{HOCl}$, we took as reference a recent determination performed in our laboratory using exactly the same analytical protocol $\left(k_{2}=8.1 \times 10^{4} \mathrm{M}^{-1} \mathrm{~s}^{-1}\right)$ [15]. Finally, and in agreement with the well-known low reactivity of Tau-NHCl [31], we found that this haloamine was unreactive with tryptophan. In fact, the experiments were done using up to a 10-fold excess of Tau- $\mathrm{NHCl}$ compared with Tau- $\mathrm{NHBr}$, but no indication of consumption of tryptophan was observed for up to $10 \mathrm{~min}$. From these results, the following reactivity sequence was obtained: $\mathrm{HOBr}>\mathrm{HOCl}>\mathrm{Tau}-\mathrm{NHBr}>\mathrm{Tau}-\mathrm{NHCl}$ (unreactive).

Besides tryptophan, the reactivity of Tau-NHBr with melatonin and serotonin was also obtained. These tryptophan derivatives have many physiological functions, including endogenous antioxidative activity [36,37]. Among others factors, this property is related to the lower one-electron reduction potential of these molecules compared to tryptophan (tryptophan $\mathrm{E}^{\circ \prime}=1.01 \mathrm{~V}$, melatonin $\mathrm{E}^{\circ \prime}=0.95 \mathrm{~V}$, and serotonin $\left.\mathrm{E}^{\circ \prime}=0.65 \mathrm{~V}\right)$ [38]. In agreement, the $k_{2}$ values obtained for melatonin $\left(7.3 \times 10^{3} \mathrm{M}^{-1} \mathrm{~s}^{-1}\right)$ and serotonin $\left(2.9 \times 10^{3} \mathrm{M}^{-1} \mathrm{~s}^{-1}\right)$ were about 10-fold higher compared to tryptophan (Figure 2).

\subsection{Reactivity with Dansylglycine}

In contrast to tryptophan, which has significant intrinsic fluorescence, other oxidizable amino acids, like methionine and cysteine, are not fluorescent. Tyrosine is also fluorescent, but with its maximum excitation/emission at 280/305 nm, our application of a stopped-flow system coupled to a LED source $(280 \mathrm{~nm})$ and the emission cut-off filters $(305 \mathrm{~nm})$ made the determination of $k_{2}$ unworkable. Thus, instead of a direct measurement of the reaction rate, an indirect procedure was performed by comparing the effect of these amino acids with the reaction rate of dansylglycine and Tau-NHBr. Dansylglycine is a fluorescent probe used for attribution of binding sites in albumin [39]. This probe was selected for several reasons, including our previous determination of its bimolecular rate constant with $\mathrm{HOBr}$ and $\mathrm{HOCl}$ [15], its fluorescence properties $\left(\lambda_{\mathrm{ex}} 360 \mathrm{~nm}, \lambda_{\mathrm{em}} 550 \mathrm{~nm}\right)$, which made the spectral interference of the studied compounds minimal, and its application as a probe for tryptophan residues in albumin, as will be demonstrated below.

Before the use of dansylglycine for the comparison of the reactivity of these amino acids, the measurement of its apparent second-order rate constant with Tau-NHBr was performed (Figure 3). Corroborant with the tryptophan results, the obtained $k_{2}\left(9.5 \times 10^{1} \mathrm{M}^{-1} \mathrm{~s}^{-1}\right)$ was significantly lower than for $\mathrm{HOBr}\left(7.3 \times 10^{6} \mathrm{M}^{-1} \mathrm{~s}^{-1}\right)$ and $\mathrm{HOCl}\left(5.2 \times 10^{2} \mathrm{M}^{-1} \mathrm{~s}^{-1}\right)$ [15]. Tau-NHCl was totally unreactive with dansylglycine. The following reactivity sequence again was established: $\mathrm{HOBr}>\mathrm{HOCl}>$ Tau-NHBr $>$ Tau-NHCl.

\subsection{Relative Reactivity with Tryptophan, Tyrosine, Cysteine and Methionine}

Following the analytical protocol established above, the selectivity of Tau-NHBr with the oxidizable amino acids was evaluated by measuring and comparing tryptophan, tyrosine, cysteine and methionine in regard to their efficacy as inhibitors of the oxidation of dansylglycine. 
The results displayed in Figure 4 show the effect of tryptophan and tyrosine in the fluorescence bleaching of dansylglycine. It can be observed that, whereas tryptophan was an effective competitor and significantly inhibited the depletion of dansylglycine, tyrosine was much less effective. From these experiments, the relative reactivity of the amino acids was calculated as the slope of the curve ( $k_{\text {obs }}$ versus amino acid concentration). The results were tryptophan $2.4 \times 10^{-4} \Delta k_{o b s} / \mathrm{mM}$ (Figure $4 \mathrm{~b}$ ) and tyrosine $1.3 \times 10^{-5} \Delta k_{o b s} / \mathrm{mM}$ (Figure $4 \mathrm{~d}$ ), showing that tryptophan was about an 18 -fold better inhibitor, or, in other words, 18 -fold more reactive with Tau-NHBr compared with tyrosine.

Following the same experimental concept, the effects of cysteine and methionine on dansylglycine bleaching were also measured. The slope of the curve of the pseudo first-order rate constant versus amino acid concentration was cysteine $8.7 \times 10^{-5} \Delta k_{\text {obs }} / \mathrm{mM}$ and methionine $6.5 \times 10^{-5} \Delta k_{\text {obs }} / \mathrm{mM}$ (Figure 5). Hence, the following sequence of relative reactivity of Tau-NHBr was established: tryptophan $>$ cysteine $\sim$ methionine $>$ tyrosine.
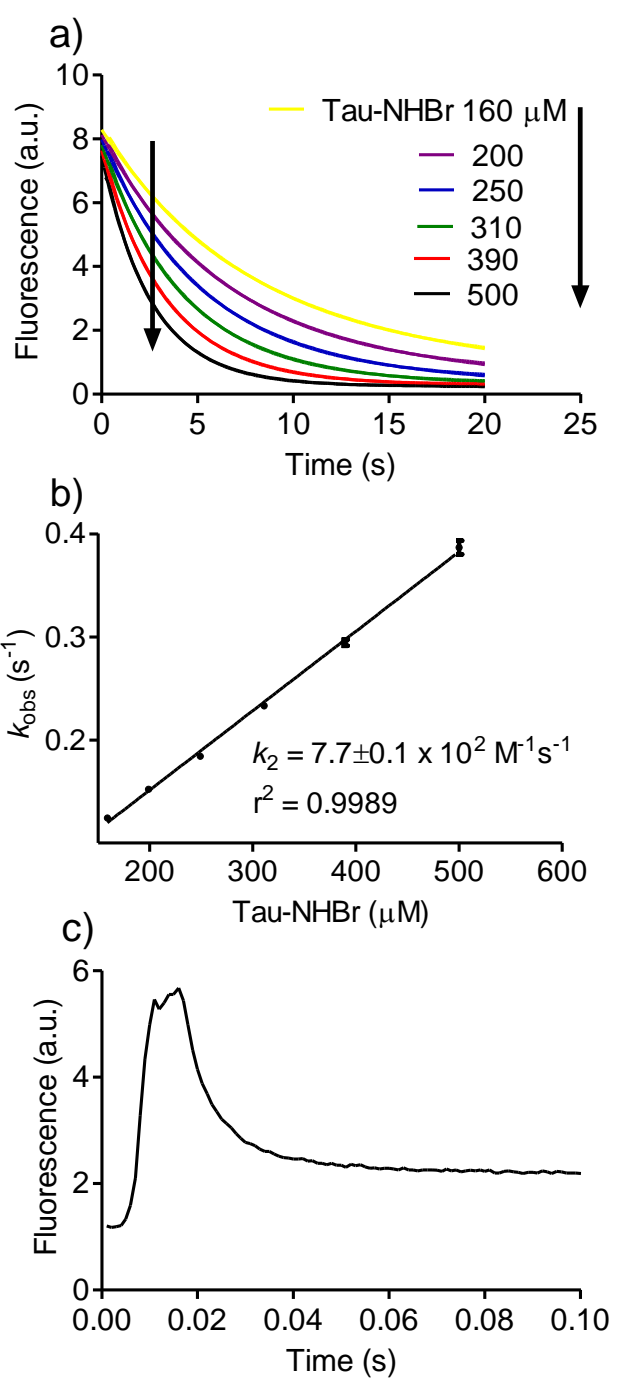

Figure 1. Reactivity of Tau-NHBr and HOBr with tryptophan. (a) Kinetic profile of tryptophan consumption for determination of $k_{o b s}$ under pseudo-first-order experimental conditions. The reaction mixture was composed of $25 \mu \mathrm{M}$ tryptophan and increasing concentrations of Tau-NHBr in $50 \mathrm{mM}$ phosphate buffer, $\mathrm{pH} 7.0$ at $25^{\circ} \mathrm{C}$. The stopped-flow system was set as follows: excitation, $280 \mathrm{~nm}$ LED; and emission, $325 \mathrm{~nm}$ cut-off filter; (b) Determination of the bimolecular rate constant $\left(k_{2}\right)$ for the reaction between tryptophan and Tau-NHBr; (c) Kinetic profile of tryptophan $(25 \mu \mathrm{M})$ consumption by $\mathrm{HOBr}(50 \mu \mathrm{M})$. The results are the mean of three experiments. 
a)

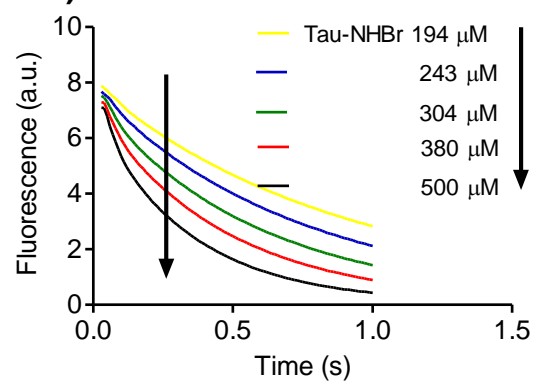

c)

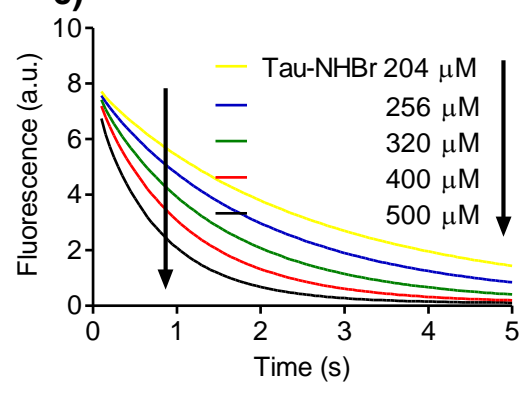

b)

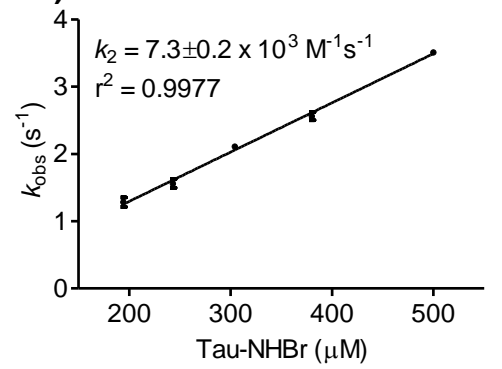

d)

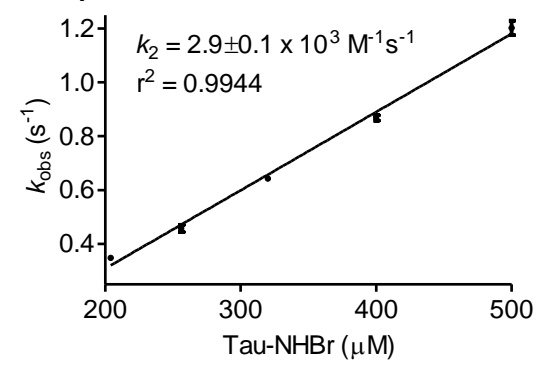

Figure 2. Reactivity of Tau-NHBr with melatonin and serotonin. Kinetic profile of (a) Melatonin and (c) Serotonin consumption for determination of $k_{o b s}$ under pseudo-first-order experimental conditions. The reaction mixture was composed of $25 \mu \mathrm{M}$ indoles and increasing concentrations of Tau-NHBr in $50 \mathrm{mM}$ phosphate buffer, $\mathrm{pH} 7.0$ at $25^{\circ} \mathrm{C}$. The stopped-flow system was set as follows: excitation, $280 \mathrm{~nm}$ LED; and emission, $325 \mathrm{~nm}$ cut-off filter. Determination of the bimolecular rate constant $\left(k_{2}\right)$ for the reaction between (b) Melatonin and (d) Serotonin with Tau-NHBr. The results are the mean of three experiments.
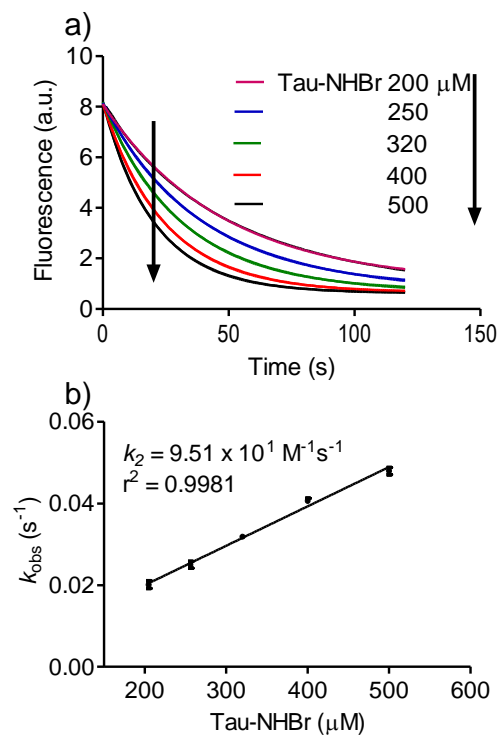

Figure 3. Reactivity of Tau-NHBr with dansylglycine. (a) Kinetic profile of dansylglycine consumption for determination of $k_{o b s}$ under pseudo-first-order experimental conditions. The reaction mixture was composed of $25 \mu \mathrm{M}$ dansylglycine (DG) and increasing concentrations of Tau- $\mathrm{NHBr}$ in $50 \mathrm{mM}$ phosphate buffer, $\mathrm{pH} 7.0$ at $25^{\circ} \mathrm{C}$. The stopped-flow system was set as follows: excitation, $360 \mathrm{~nm}$ LED; and emission, $475 \mathrm{~nm}$ cut-off filter; (b) Determination of $k_{2}$ for the reaction between dansylglycine and Tau-NHBr. The results are the mean of three experiments. 

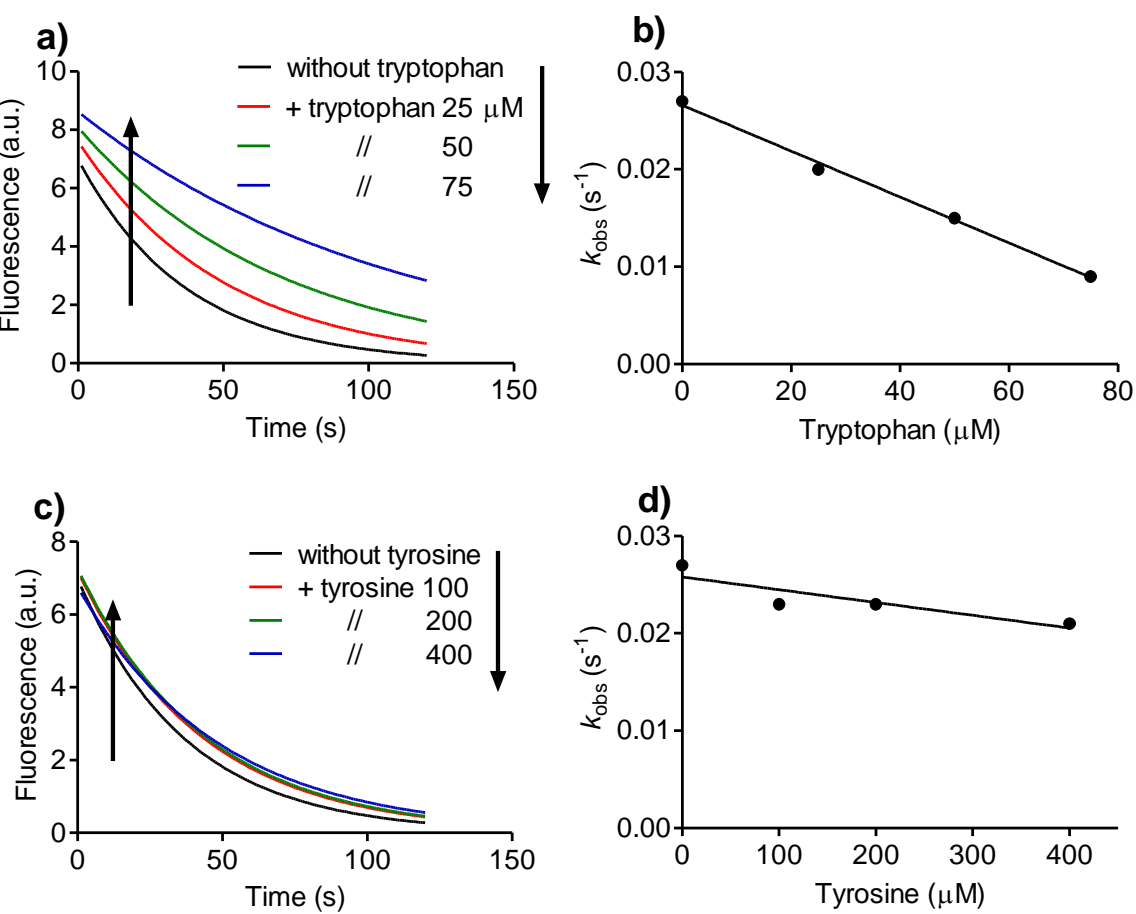

Figure 4. Tryptophan versus tyrosine as targets for Tau-NHBr. (a) Reaction of dansylglycine with Tau-NHBr and the effect of tryptophan; (b) Effect of tryptophan on the pseudo-first-order reaction rate of dansylglycine with Tau-NHBr; (c) Reaction of dansylglycine with Tau-NHBr and the effect of tyrosine; (d) Effect of tyrosine on the pseudo-first-order reaction rate of dansylglycine with Tau-NHBr. The reaction mixture was composed of $25 \mu \mathrm{M}$ dansylglycine, $500 \mu \mathrm{M}$ Tau- $\mathrm{NHBr}$ and increasing concentrations of amino acids in $50 \mathrm{mM}$ phosphate buffer, $\mathrm{pH}$ 7.0. The stopped-flow system was set as follows: excitation, $360 \mathrm{~nm}$ LED; and emission, $475 \mathrm{~nm}$ cut-off filter.

\subsection{Selectivity upon Tryptophan Residues in Proteins}

As we have demonstrated above, Tau-NHBr has lower oxidant capacity compared to its precursor $\mathrm{HOBr}$ and $\mathrm{HOCl}$. In this context, it is worth noting a principle of chemistry: lower reactivity usually implies greater selectivity. This principle seems to be applicable in our studies, because, in contrast to $\mathrm{HOBr}$ and $\mathrm{HOCl}$, Tau-NHBr was able to oxidize tryptophan but not tyrosine. Following this idea, we suspect that our recent proposal for the selectivity of Tau-NHBr [40] and Tau- $\mathrm{NBr}_{2}$ [41] for tryptophan residues in albumin and lysozyme could be reinforced by these new findings. Thus, aiming to advance this proposal, dansylglycine was used to probe the depletion of tryptophan in human serum albumin (HSA).

Dansylglycine is a ligand of albumin. Its complexation can be monitored by an increased fluorescence quantum yield and a blue shift in the emission band, and, more importantly for our purpose, dansylated amino acids can be excited by fluorescence resonance energy transfer from tryptophan in HSA [42]. To make sure that this property is also applicable to dansylglycine, we added increasing concentrations of this compound to a fixed concentration of HSA. Our expectation was confirmed because dansylglycine was not fluorescent when excited at $295 \mathrm{~nm}$; however, in the presence of HSA, the addition of increasing amounts of dansylglycine provoked a gradual quenching of the intrinsic fluorescence of the protein and a concomitant increase in the fluorescence of dansylglycine.

Considering these findings, dansylglycine was used as a probe for evaluation of the consumption of tryptophan in HSA provoked oxidation. In these experiments, the oxidation was provoked by adding a 20-fold excess of the oxidants and, after five minutes, methionine was added to deplete the excess of oxidants. The results depicted in Figure 6a confirmed our expectation of selectivity because, though much less reactive with free tryptophan, $\mathrm{Tau}-\mathrm{NHBr}$ was more effective than $\mathrm{HOCl}$ or $\mathrm{HOBr}$ in 
depleting the intrinsic fluorescence of HSA, which is mainly due to tryptophan residues when excited at $295 \mathrm{~nm}$ [43]. In others words, Tau-NHBr seems to act mainly on tryptophan residues of the protein. Figure $6 \mathrm{~b}$ shows the effect of the addition of dansylglycine after oxidation and depletion of the oxidant excess. The band at $485 \mathrm{~nm}$ was lower in the sample oxidized with Tau-NHBr, which is an additional confirmation that tryptophan residues were more efficiently oxidized using this oxidant, since the measured fluorescence was due to energy transfer from the tryptophan residues in HSA.
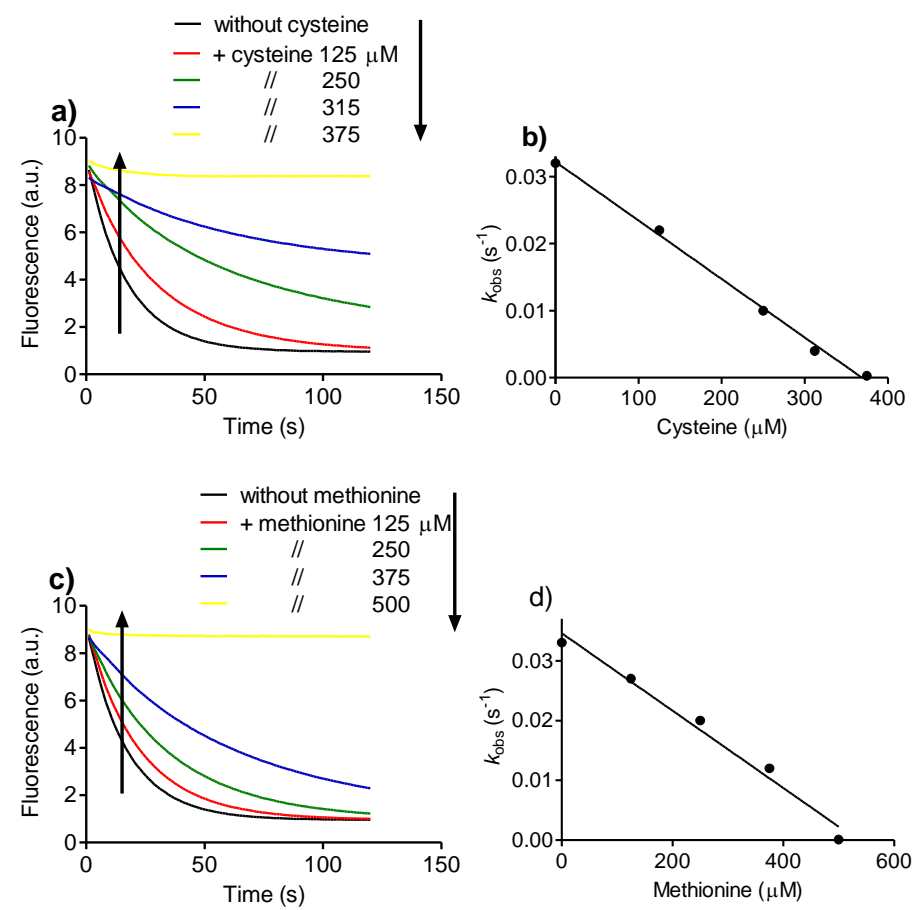

Figure 5. Cysteine versus methionine as targets for Tau-NHBr. (a) Reaction of dansylglycine with Tau-NHBr and the effect of cysteine; (b) Effect of cysteine on the pseudo-first-order reaction rate of dansylglycine with Tau-NHBr; (c) Reaction of dansylglycine with Tau-NHBr and the effect of methionine; (d) Effect of methionine on the pseudo-first-order reaction rate of dansylglycine with Tau-NHBr. The reaction mixture was composed of $25 \mu \mathrm{M}$ dansylglycine, $500 \mu \mathrm{M}$ Tau-NHBr and increasing concentrations of amino acids in $50 \mathrm{mM}$ phosphate buffer, $\mathrm{pH}$ 7.0. The stopped-flow system was set as follows: excitation, $360 \mathrm{~nm}$ LED; and emission, $475 \mathrm{~nm}$ cut-off filter.

\subsection{Comparison between Tau-NHCl and $\mathrm{Tau}-\mathrm{NHBr}$}

As we have demonstrated above, Tau- $\mathrm{NHCl}$ was unreactive with all studied compounds in this work; which is, indeed, in agreement with its well-established poor oxidant capacity [32]. Obviously, it does not mean that Tau- $\mathrm{NHCl}$ is completely devoid of oxidant capacity, as is confirmed, for instance, by its capacity to oxidize sulfhydryl residues in proteins [27]. Tau- $\mathrm{NHCl}$ is also able to oxidize 3,3',5,5'-tetramethylbenzidine (TMB) in acid medium, the chromogenic substrate used for determination of the chlorination activity of MPO [44]. Thus, aiming to quantify the difference in reactivity between $\mathrm{Tau}-\mathrm{NHBr}$ and $\mathrm{Tau}-\mathrm{NHCl}$, we used $\mathrm{TMB}$ as the target. It must also be noted that instead of an acidic $\mathrm{pH}$, the reaction was conducted at $\mathrm{pH} \mathrm{7.0,} \mathrm{as} \mathrm{was} \mathrm{used} \mathrm{for} \mathrm{the} \mathrm{other}$ compound studies in this work. It is important to emphasize this point, because its reactivity is significantly lower at neutral $\mathrm{pH}$, which is, indeed, the reason for the application of acidic medium for determination of Tau-NHCl activity using TMB [44]. The results depicted in Figure 7 confirmed our expectation, because, at $\mathrm{pH}$ 7.0, Tau- $\mathrm{NHCl}$ was able to oxidize TMB. Its oxidant efficacy was measured $\left(k_{2}=3.1 \mathrm{M}^{-1} \mathrm{~s}^{-1}\right)$ and, corroborant with the previous results, was about 100-fold lower than Tau- $\mathrm{NHBr}$ $\left(k_{2}=6.4 \times 10^{2} \mathrm{M}^{-1} \mathrm{~s}^{-1}\right)$. The comparison was also made using the antioxidant curcumin, an oxidizable 
polyphenol, as the target. The rate constants were $7.3 \mathrm{M}^{-1} \mathrm{~s}^{-1}$ and $38.2 \mathrm{M}^{-1} \mathrm{~s}^{-1}$ for Tau- $\mathrm{NHCl}$ and Tau-NHBr, respectively (Figure 7).
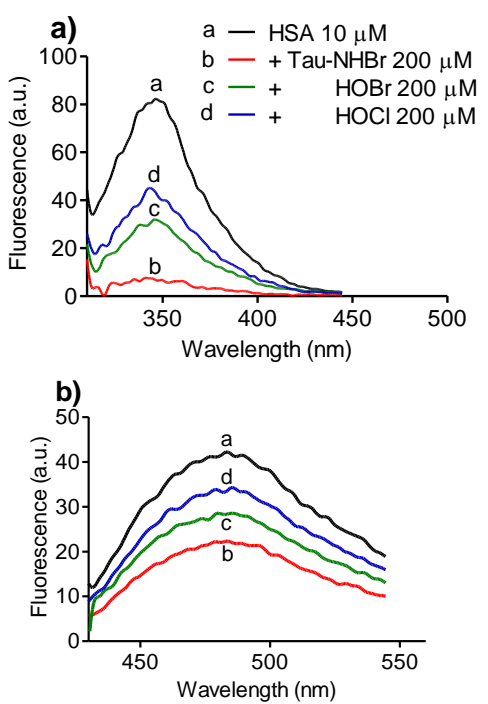

Figure 6. Oxidation of $\mathrm{HSA}$ by $\mathrm{HOBr}, \mathrm{HOCl}$ and Tau-NHBr. (a) Reaction mixtures were composed of $10 \mu \mathrm{M}$ HSA and $200 \mu \mathrm{M}$ oxidants in $5.0 \mathrm{mM}$ phosphate buffer, $\mathrm{pH}$ 7.0. After five minutes, $250 \mathrm{mM}$ methionine was added and the HSA intrinsic fluorescence was measured at an excitation of $295 \mathrm{~nm}$; (b) Addition of $5 \mu \mathrm{M}$ dansylglycine to the oxidized protein and its fluorescence obtained by energy transfer from tryptophan residues.

a)

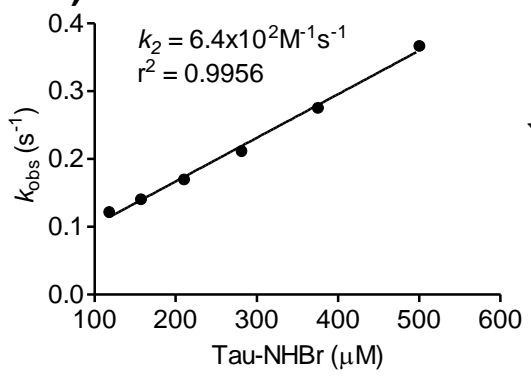

c)

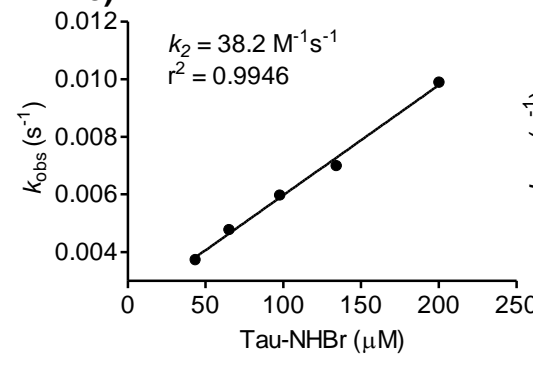

b)

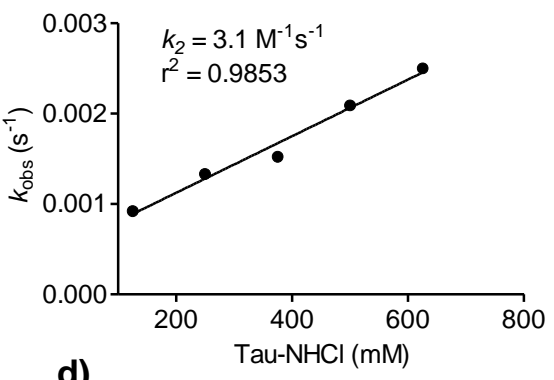

d)

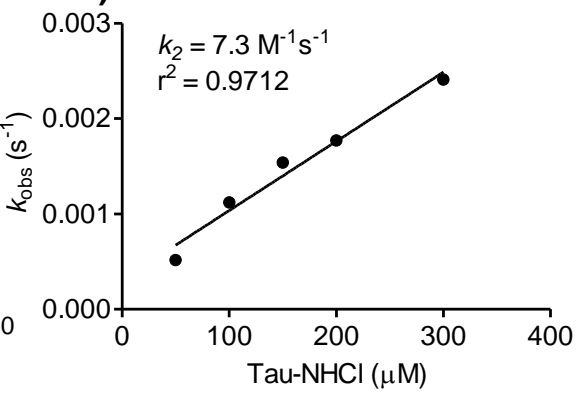

Figure 7. Tau-NHBr versus $\mathrm{TauNHCl}$ as oxidants of tetramethylbenzidine and curcumin. $(\mathbf{a}, \mathbf{b})$ Determination of bimolecular rate constant $\left(k_{2}\right)$ for the reaction between TMB and Tau-NHBr or Tau-NHCl. The reaction mixture was composed of $1.4 \mathrm{mM} \mathrm{TMB}$ and increasing concentrations of haloamines in $50 \mathrm{mM}$ phosphate buffer, $\mathrm{pH} 7.0 ;(\mathbf{c}, \mathbf{d})$ Determination of the bimolecular rate constants $\left(k_{2}\right)$ for the reactions between curcumin and Tau-NHBr or Tau-NHCl. The reaction mixture was composed of $10 \mu \mathrm{M}$ curcumin and increasing concentrations of haloamines in $50 \mathrm{mM}$ phosphate buffer, pH 7.0. 


\section{7. pH Effect on Tau-NHBr Reactivity}

In aqueous solutions, chloramine and bromamine are in equilibrium with their dichloramine and dibromamine forms $[32,33]$. These dihalogenated structures are the results of the disproportionation reaction, by which two molecules of Tau-NHX are converted to Tau- $\mathrm{NX}_{2}$ and taurine, respectively. The conversion of Tau- $\mathrm{NHCl}$ to Tau- $\mathrm{NHCl}_{2}$ is $\mathrm{pH}$ dependent, being favored at acidic $\mathrm{pH}$ [32]. Here, we found the same tendency for Tau-NHBr, which was progressively, converted to Tau- $\mathrm{NBr}_{2}$ as the $\mathrm{pH}$ decreased. The results depicted in Figure 8a show the absorbance increase at 241 and $346 \mathrm{~nm}$ and decrease at $288 \mathrm{~nm}$, which provides evidence for the formation of $\mathrm{Tau}^{-\mathrm{NBr}_{2}}$ [33]. The chemical equation below shows the equilibrium between the mono- and dihalogenated forms as well as the $\mathrm{pH}$ dependence (Equation 2).

$$
\begin{array}{rlll}
2 \mathrm{HO}_{3} \mathrm{SCH}_{2} \mathrm{CH}_{2} \mathrm{NHBr}+ \\
(\mathrm{Tau}-\mathrm{NHBr})
\end{array} \quad \mathrm{H}^{+} \leftrightarrow \quad \begin{aligned}
& \mathrm{HO}_{3} \mathrm{SCH}_{2} \mathrm{CH}_{2} \mathrm{NBr}_{2} \\
& \left(\mathrm{Tau}-\mathrm{NBr}_{2}\right)
\end{aligned} \quad \begin{aligned}
& +\mathrm{HO}_{3} \mathrm{SCH}_{2} \mathrm{CH}_{2} \mathrm{NH}_{3}^{+} \\
& \text {(Taurine) }
\end{aligned}
$$
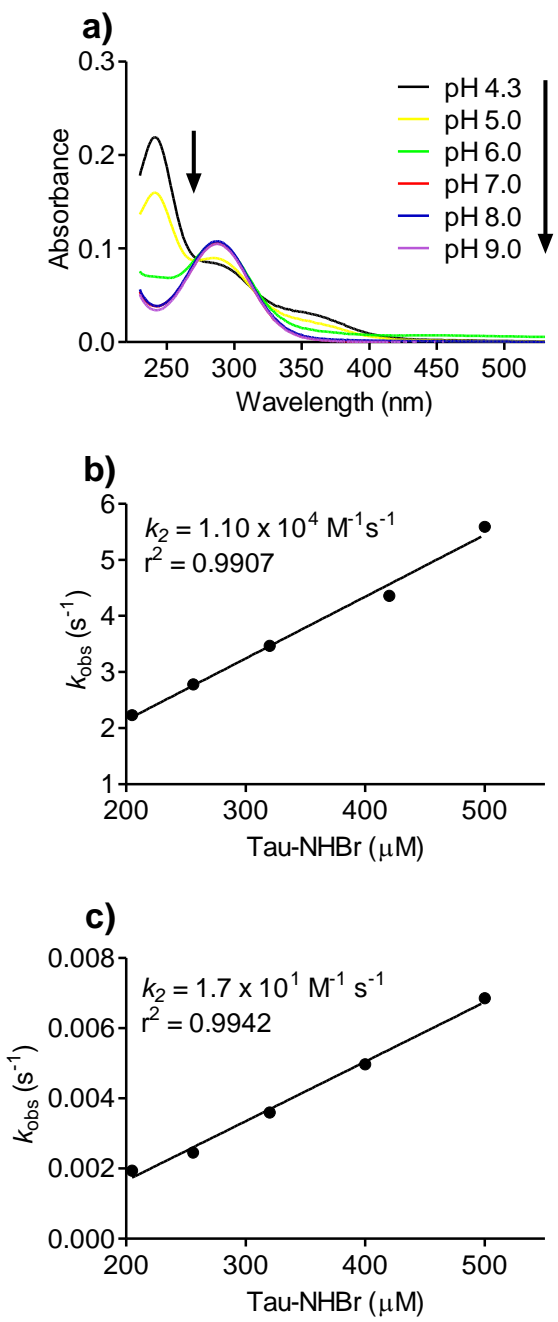

Figure 8. $\mathrm{pH}$ effect on Tau-NHBr reactivity. (a) Tau-NHBr $(5 \mathrm{mM})$ was prepared in water using a 100 -fold excess of taurine. The solution was diluted to $0.25 \mathrm{mM}$ of $\mathrm{NaH}_{2} \mathrm{PO}_{4} / \mathrm{Na}_{2} \mathrm{HPO}_{4}(50 \mathrm{mM})$ solutions combined to reach the indicated $\mathrm{pH} ;(\mathbf{b}, \mathbf{c})$ Reactivity of Tau-NHBr with dansylglycine at $\mathrm{pH}$ 5.0 and 9.0 .

Next, we studied the effect of $\mathrm{pH}$ on the reactivity of Tau-NHBr. Figure 8 shows the $k_{2}$ obtained for the reactions between dansylglycine and Tau-NHBr at $\mathrm{pH} 5.0$ and 9.0. The rate constants were (pH 5.0) 
$1.1 \times 10^{4} \mathrm{M}^{-1} \mathrm{~s}^{-1}$, $(\mathrm{pH} 7.0) 9.5 \times 10^{1} \mathrm{M}^{-1} \mathrm{~s}^{-1}$ and $(\mathrm{pH} 9.0) 1.7 \times 10^{1} \mathrm{M}^{-1} \mathrm{~s}^{-1}$. The $\mathrm{pH}$ dependence can be explained by taking into account the higher reactivity of the dihalogenated forms, as has been demonstrated for Tau- $\mathrm{NCl}_{2}$ [45].

\subsection{Reactivity of Tau-NHBr with Hydrogen Peroxide and Formation of Singlet Oxygen}

Another property that distinguishes Tau- $\mathrm{NHCl}$ from $\mathrm{Tau}-\mathrm{NHBr}$ is the capacity of the latter to react with $\mathrm{H}_{2} \mathrm{O}_{2}$ [33]. Here, this chemical property was confirmed and the $k_{2}\left(3.9 \mathrm{M}^{-1} \mathrm{~s}^{-1}\right)$ obtained by measuring the decay of Tau-NHBr as a function of increasing concentrations of $\mathrm{H}_{2} \mathrm{O}_{2}$ (Figure 9).
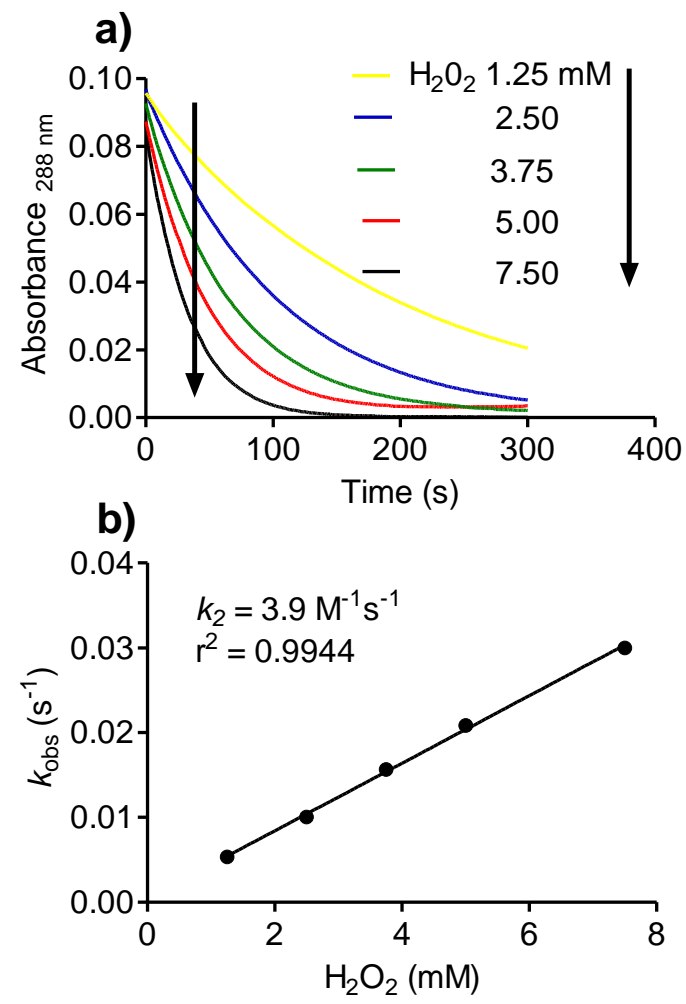

Figure 9. Reactivity of Tau-NHBr with $\mathrm{H}_{2} \mathrm{O}_{2}$. (a) Kinetic profile of Tau-NHBr consumption for determination of kobs under pseudo-first-order experimental conditions. The reaction mixture was composed of $250 \mu \mathrm{M}$ Tau-NHBr and increasing concentrations of $\mathrm{H}_{2} \mathrm{O}_{2}$ in $50 \mathrm{mM}$ phosphate buffer, $\mathrm{pH} 7.0$; (b) Determination of the bimolecular rate constant $\left(k_{2}\right)$ for the reaction between $\mathrm{H}_{2} \mathrm{O}_{2}$ and Tau-NHBr.

Activated eosinophils are an important in vivo source of singlet oxygen. The formation of this electronically excited form of oxygen is due to the reaction between $\mathrm{HOBr}$ and $\mathrm{H}_{2} \mathrm{O}_{2}$ [46]. We found that Tau-NHBr retains this capacity, as can be seen by the ultra-weak light emission produced during the reaction course originating from the decay of singlet oxygen (Figure 10a). It is important to emphasize that the extremely low light emission is due to the inadequacy of a conventional luminometer to measure the emission of singlet oxygen, which emits in the infrared region $(1200 \mathrm{~nm})$. Hence, to gain additional evidence of its production, we added melatonin to the reaction system. The results depicted in Figure 10b show that the light emission increased almost two orders of magnitude compared to the reaction without melatonin. The light emission is dependent on both $\mathrm{H}_{2} \mathrm{O}_{2}$ and melatonin, which excluded the possibility of direct interaction between melatonin and Tau- $\mathrm{NHBr}$ or melatonin and $\mathrm{H}_{2} \mathrm{O}_{2}$ as a source of the light emission. Thus, the increase in emission is consistent with the cleavage of the pyrrole ring of melatonin and formation of $N$-acetyl- $N$-formyl-5-methoxykynuramine (AFMK), a 
chemiluminescent reaction [47] that has been demonstrated between melatonin and singlet oxygen [48]. In accordance with this proposal, the formation of AFMK was also obtained here (Figure 10c).

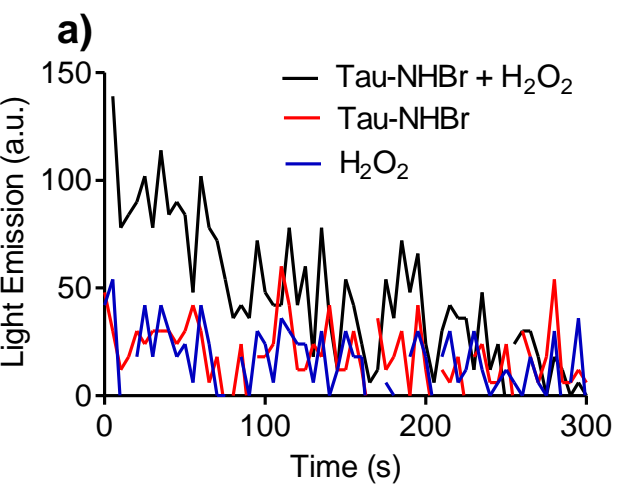

b)
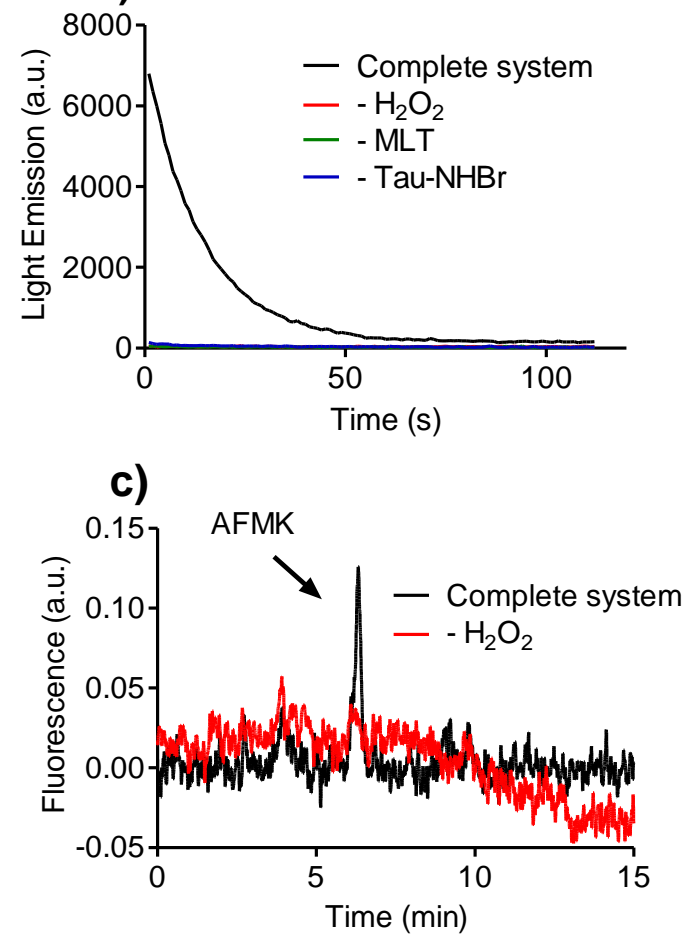

Figure 10. Evidence of oxygen singlet production. (a) Intrinsic light emission by the reaction of $0.25 \mathrm{mM}$ Tau-NHBr with $5 \mathrm{mM} \mathrm{H}_{2} \mathrm{O}_{2}$ in $50 \mathrm{mM}$ phosphate buffer, $\mathrm{pH}$ 7.0; (b) Melatonin-mediated light emission by the reaction consisting of $0.25 \mathrm{mM}$ Tau-NHBr with $5 \mathrm{mM} \mathrm{H}_{2} \mathrm{O}_{2}$ and $1 \mathrm{mM}$ melatonin in $50 \mathrm{mM}$ phosphate buffer, pH 7.0 (complete system); (c) HPLC analysis of the reaction mixture and evidence of the formation of AFMK (peak at $6 \mathrm{~min}$ ) obtained by comparison with a pure AFMK.

\subsection{Reactivity of Tau-NHBr with Linoleic Acid}

Among the biomolecules susceptible to the deleterious effects provoked by reactive oxygen species (ROS), unsaturated fatty acids occupy an important position. As electrophilic reagents, $\mathrm{HOCl}$ and $\mathrm{HOBr}$ are well established as inducers of the formation of halohydrin by reacting with the double bonds in mono- and polyunsaturated fatty acids $[49,50]$. For this reason, we also investigated the reactivity of Tau-NHBr with linoleic acid as a model of polyunsaturated fatty acids. In these experiments, linoleic acid was incubated with the oxidants and their remaining concentration was measured using the sulfhydryl reagent 5'-thio-2-nitrobenzoic acid (TNB). The results depicted in Figure 11 show that, while $\mathrm{HOCl}$ and $\mathrm{HOBr}$ reacted promptly with linoleic acid and were totally consumed just after one minute 
of incubation, Tau-NHBr reacted slowly, with only 50\% consumed in 60 min of incubation. As could be expected from the previous results, Tau- $\mathrm{NHCl}$ was still less reactive.

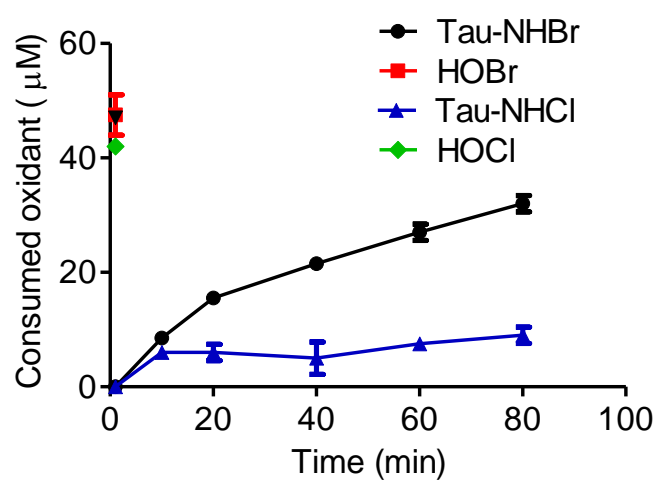

Figure 11. Reactivity with linoleic acid. The reaction mixtures were composed of $50 \mu \mathrm{M}$ Tau-NHBr, Tau-NHCl, $\mathrm{HOBr}$, or $\mathrm{HOCl}$ and $100 \mu \mathrm{M}$ linoleic acid in $50 \mathrm{mM}$ phosphate buffer, $\mathrm{pH}$ 7.0. After the indicated time, the remaining oxidants were measured by the TNB method. The results are the mean of three experiments. $\mathrm{HOCl}$ and $\mathrm{HOBr}$ were totally consumed in the first minute of reaction.

\subsection{Reactivity of Tau-NHBr with Nucleosides}

Other well established endogenous targets for hypohalous acids are nucleosides, nucleotides, DNA and RNA. For instance, 5-chlorouracil and 5-bromouracil are formed from the MPO catalyzed oxidation of uracil, and 5-chloro-2'-deoxycytidine, 8-chloro-2'-deoxyadenosine and 8-chloro-2'-deoxyguanosine result from the treatment of DNA with $\mathrm{HOCl}$ [51]. Recently, the miscoding properties of 8-chloro-2'-deoxyguanosine have been demonstrated, which highlights the potential importance of $\mathrm{HOCl}$-mediated reactions in the pathogenesis of inflammation-driven carcinogenesis [52]. Similarly, the presence of 8-bromo-2'-deoxyguanosine has been proposed as a substance that may increase mutagenic potential at the site of inflammation [53]. For this reason, we also evaluated the reactivity of Tau-NHBr with nucleosides. However, the superposition of absorption spectra between Tau-NHBr, and the nucleosides impeded the direct measurement of their consumption. Hence, we again employed an indirect experimental approach by incubating the nucleosides with the oxidant and then measuring the remaining oxidant with the TNB reagent. The results depicted in Figure 12 show that, in contrast to $\mathrm{HOBr}$, Tau-NHBr was significantly less reactive with nucleosides.

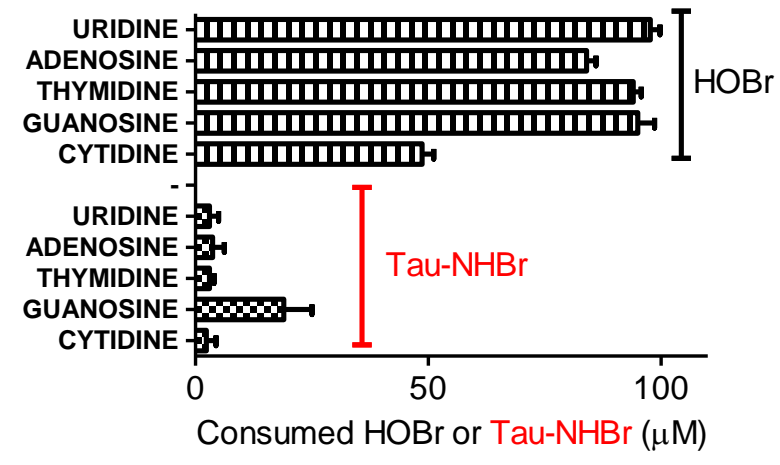

Figure 12. Reactivity of Tau-NHBr and $\mathrm{HOBr}$ with nucleosides. The reaction mixtures were composed of $100 \mu \mathrm{M}$ Tau-NHBr or $\mathrm{HOBr}$ and $100 \mu \mathrm{M}$ nucleosides in $50 \mathrm{mM}$ phosphate buffer, $\mathrm{pH}$ 7.0. After $30 \mathrm{~min}$ the remaining oxidants were measured by the TNB method. The results are the mean of three experiments. 


\section{Experimental Section}

\subsection{Chemicals and Solutions}

Taurine, tryptophan, tyrosine, methionine, cysteine, melatonin, serotonin, $N$-acetyl- $N$-formyl-5methoxykynuramine (AFMK), TMB, 5,5'-dithiobis-(2-nitrobenzoic acid) (DTNB), dansylglycine, linoleic acid, salicylic acid, curcumin, adenosine, cytidine, guanosine, thymidine, uridine and HSA were purchased from Sigma-Aldrich Chemical Co. (St. Louis, MO, USA). The chemicals used for preparation of phosphate buffers and others solutions were of analytical grade. $\mathrm{HOCl}$ was prepared by diluting a $5 \%$ stock solution and the concentration was determined spectrophotometrically after dilution in $0.01 \mathrm{M} \mathrm{NaOH}, \mathrm{pH} 12\left(\varepsilon_{292 \mathrm{~nm}}=350 \mathrm{M}^{-1} \mathrm{~cm}^{-1}\right)$. HOBr was synthesized by combining $100 \mathrm{mM} \mathrm{HOCl}$ and $200 \mathrm{mM} \mathrm{NaBr}$ in water [33]. Tau-NHCl was prepared by the addition of $5 \mathrm{mM}$ $\mathrm{HOCl}$ to $50 \mathrm{mM}$ taurine in $50 \mathrm{mM}$ sodium phosphate buffer at $\mathrm{pH} 7.0$ and its concentration was determined spectrophotometrically $\left(\varepsilon_{252 \mathrm{~nm}}=429 \mathrm{M}^{-1} \mathrm{~cm}^{-1}\right)$ [25]. Tau-NHBr was prepared by the addition of $5 \mathrm{mM}$ HOBr to $500 \mathrm{mM}$ taurine in $50 \mathrm{mM}$ sodium phosphate buffer at $\mathrm{pH} 7.0$ and its concentration was determined spectrophotometrically $\left(\varepsilon_{288 \mathrm{~nm}}=430 \mathrm{M}^{-1} \mathrm{~cm}^{-1}\right)$ [25]. TNB solution was prepared by dissolving $2 \mathrm{mM}$ DTNB in $50 \mathrm{mM}$ phosphate buffer, $\mathrm{pH}$ 7.0. Then, this solution was titrated to $\mathrm{pH} 12$ with $0.1 \mathrm{M} \mathrm{NaOH}$ to promote its hydrolysis, and after 5 min the $\mathrm{pH}$ was brought back to 7.4 with hydrochloric acid. Then, its concentration was determined by its absorbance $\left(\varepsilon_{412 \mathrm{~nm}}=14,100 \mathrm{M}^{-1} \mathrm{~cm}^{-1}\right)$ [54]. A Perkin Elmer Lambda $35 \mathrm{UV}$-visible spectrophotometer (Manufacturer, Shelton, CT, USA) was used for the UV-Vis measurements.

\subsection{Determination of Rate Constants}

The reactivity of $\mathrm{Tau}-\mathrm{NHBr}, \mathrm{HOBr}$ and $\mathrm{HOCl}$ with the target molecules was obtained by comparing their bimolecular rate constants, which were obtained using pseudo-first-order experimental conditions. The fast-kinetic experiments were performed using a single-mixing stopped-flow system equipped with a high intensity LED source and cut-off filters (SX20/LED Stopped-Flow System, Applied Photophysics, City, UK). The observed pseudo-first-order rate constant $\left(k_{o b s}\right)$ was obtained by fitting the fluorescence or absorbance decay of the studied compound to a single exponential decay equation, as follows (Equation 3):

$$
S=S_{0} \times e^{-k_{o b s} \times t}
$$

where:

$\mathrm{S}$ is the fluorescence or absorbance as a function of time $\mathrm{S}_{0}$ is the initial fluorescence or absorbance

From the $k_{\mathrm{obs}}$ values obtained at various concentrations, the bimolecular rate constants $\left(k_{2}\right)$ were calculated from the slope of the linear regression as follows (Equation 4):

$$
\text { reaction rate }=k_{2} \times[A] \times[B] \text {, }
$$

where [A] is the concentration of the haloamines or hypohalous acids and [B] is the concentration of the studied compounds. From the pseudo-first-order experimental condition, the apparent second-order rate constant $\left(k_{2}\right)$ was calculated (Equation 5).

$$
\begin{gathered}
\text { If }[A] \gg[B], \text { then, reaction rate }=k_{o b s} \times[B] \\
\text { Then, } k_{o b s}=k_{2} \times[A]
\end{gathered}
$$

The $k_{2}$ is the slope of the linear fit of $k_{o b s}$ versus [A]

The photophysical properties of the studied compounds and their intrinsic reactivity determined the experimental conditions used to monitor each reaction. The specific absorbance or excitation 
and emission wavelengths used for monitoring each reaction are shown in the figure legends. Unless otherwise stated, the concentrations of the target compounds were fixed at $25 \mu \mathrm{M}$, and the concentrations of the oxidants were in the range of 100 to $500 \mu \mathrm{M}$. The reactions were performed in $50 \mathrm{mM}$ phosphate buffer, $\mathrm{pH} 7.0$ at $25^{\circ} \mathrm{C}$.

\subsection{Oxidation of Human Albumin and the Use of Dansylglycine as a Fluorescent Probe for Tryptophan Residues}

The reaction mixtures were composed of $10 \mu \mathrm{M}$ HSA and $200 \mu \mathrm{M}$ oxidants in $50 \mathrm{mM}$ phosphate buffer, $\mathrm{pH}$ 7.0. After five minutes, $250 \mu \mathrm{M}$ methionine was added and the fluorescence was measured at an excitation wavelength of $295 \mathrm{~nm}$ and emission in the range of 310-450 $\mathrm{nm}$ was recorded. When present, dansylglycine was added at $5 \mu \mathrm{M}$ and emission was measured in the range of 450-600 $\mathrm{nm}$. The experiments were performed using a LS55 spectrofluorometer (Perkin-Elmer, Waltham, MA, USA). For the experiments where HSA was oxidized in the presence of dansylglycine, the stopped-flow system was set as follows: excitation, $280 \mathrm{~nm}$ LED, and emission, $455 \mathrm{~nm}$ cut-off filter.

\subsection{Reactions with 3,3',5,5'-tetramethylbenzidine (TMB), Curcumin, Hydrogen Peroxide and Linoleic Acid}

3,3',5,5'-tetramethylbenzidine: The reaction medium was composed of $1.4 \mathrm{mM} \mathrm{TMB}$ and increasing concentrations of haloamines in $50 \mathrm{mM}$ phosphate buffer, $\mathrm{pH}$ 7.0. The reaction was monitored at $650 \mathrm{~nm}$ using conventional spectrophotometry.

Curcumin: The reaction medium was composed of $10 \mu \mathrm{M}$ curcumin and increasing concentrations of haloamines in $50 \mathrm{mM}$ phosphate buffer, $\mathrm{pH}$ 7.0. The reaction was monitored at $425 \mathrm{~nm}$ using conventional spectrophotometry.

Hydrogen peroxide: The reaction medium was composed of $250 \mu \mathrm{M}$ Tau-NHBr and increasing concentrations of $\mathrm{H}_{2} \mathrm{O}_{2}$ in $50 \mathrm{mM}$ phosphate buffer, $\mathrm{pH}$ 7.0. The reaction was monitored at $288 \mathrm{~nm}$ using conventional spectrophotometry. The reaction also was studied by chemiluminescence. In this case, the measurement of light emission was performed using a Centro LB 960 microplate luminometer (Berthold Technologies, Oak Ridge, TN, USA). The isolation and identification of oxidation products of melatonin was performed by high performance liquid chromatography in line with a fluorescence detector set at 340/460 nm (Jasco, Easton, MD, USA). The analyses were carried out isocratically on a Luna C18 reverse-phase column $(250 \times 4.6 \mathrm{~mm}, 5 \mu \mathrm{m})$ using 70:30 aqueous formic acid $0.1 \%$ /acetonitrile (flow rate $1.0 \mathrm{~mL} / \mathrm{min}$ ) as the mobile phase. The identification of AFMK as a product of the reaction was performed by comparison with a pure standard of this compound.

Linoleic acid: The oxidants $(50 \mu \mathrm{M})$ were incubated with $100 \mu \mathrm{M}$ linoleic acid in $50 \mathrm{mM}$ phosphate buffer, $\mathrm{pH} 7.0$ for increasing time intervals. Then, the remaining concentration of oxidants was measured by the addition of $50 \mu \mathrm{M} \mathrm{TNB}$, and the absorbance was measured at $412 \mathrm{~nm}\left(\varepsilon_{412 \mathrm{~nm}}=14,100 \mathrm{M}^{-1} \mathrm{~cm}^{-1}\right)$.

\section{Conclusions}

Tau-NHBr, an endogenous oxidant, has also been used as an anti-inflammatory compound and topical antimicrobial agent. Here, we have identified several chemical properties of this promising drug. The most important was its selectivity regarding tryptophan residues in proteins. By measuring the bimolecular rate constant with several biomolecules, the following reactivity sequence was established: $\mathrm{HOBr}>\mathrm{HOCl}>\mathrm{Tau}-\mathrm{NHBr}>\mathrm{Tau}-\mathrm{NHCl}$. The reactivity of Tau-NHBr was strongly affected by the $\mathrm{pH}$ of the medium, a property related to the formation of the dibromamine form at acidic $\mathrm{pH}$ (Tau-NBr2). The formation of singlet oxygen was observed in the reaction between Tau-NHBr and $\mathrm{H} 2 \mathrm{O} 2$. In conclusion, these findings could be very helpful for researchers interested in biological applications of this taurine haloamine.

Acknowledgments: This work was supported by grants (2013/08784-0 and 2105/08267-1) from the São Paulo Research Foundation (FAPESP), Coordination for Enhancement of Higher Education Personnel (CAPES) and National Council for Scientific and Technological Development (CNPq, 440503/2014-0). 
Author Contributions: Valdecir Farias Ximenes and Luiza De Carvalho Bertozo conceived and designed the experiments; Valdecir Farias Ximenes and Luiza De Carvalho Bertozo performed the experiments; Valdecir Farias Ximenes, Aguinaldo Robinson De Souza, Nelson Henrique Morgon and Luiza de Carvalho Bertozo analyzed the data; Valdecir Farias Ximenes wrote the paper.

Conflicts of Interest: The authors declare no conflict of interest.

\section{References}

1. Wang, G.; Nauseef, W.M. Salt, chloride, bleach, and innate host defense. J. Leukoc. Biol. 2015, 98, $163-172$. [CrossRef] [PubMed]

2. Klion, A.D.; Nutman, T.B. The role of eosinophils in host defense against helminth parasites. J. Allergy Clin. Immunol. 2004, 113, 30-37. [CrossRef] [PubMed]

3. Hasegawa, K.; Stoll, S.J.; Ahn, J.; Bittner, J.C.; Camargo, C.A., Jr. Prevalence of eosinophilia in hospitalized patients with asthma exacerbation. Respir. Med. 2015, 109, 1230-1232. [CrossRef] [PubMed]

4. Thomson, E.; Brennan, S.; Senthilmohan, R.; Gangell, C.L.; Chapman, A.L.; Sly, P.D.; Kettle, A.J.; Australian Respiratory Early Surveillance Team for Cystic Fibrosis (AREST CF); Balding, E.; Berry, L.J.; et al. Identifying peroxidases and their oxidants in the early pathology of cystic fibrosis. Free Radic. Biol. Med. 2010, 49, 1354-1360. [CrossRef] [PubMed]

5. Shao, B.; Tang, C.; Sinha, A.; Mayer, P.S.; Davenport, G.D.; Brot, N.; Oda, M.N.; Zhao, X.Q.; Heinecke, J.W. Humans with atherosclerosis have impaired ABCA1 cholesterol efflux and enhanced high-density lipoprotein oxidation by myeloperoxidase. Circ. Res. 2014, 114, 1733-1742. [CrossRef] [PubMed]

6. Ortega, H.; Katz, L.; Gunsoy, N.; Keene, O.; Yancey, S. Blood eosinophil counts predict treatment response in patients with severe eosinophilic asthma. J. Allergy. Clin. Immunol. 2015, 136, 825-826. [CrossRef] [PubMed]

7. Aldridge, R.E.; Chan, T.; van Dalen, C.J.; Senthilmohan, R.; Winn, M.; Venge, P.; Town, G.I.; Kettle, A.J. Eosinophil peroxidase produces hypobromous acid in the airways of stable asthmatics. Free Radic. Biol. Med. 2002, 33, 847-856. [CrossRef]

8. Acharya, K.R.; Ackerman, S.J. Eosinophil granule proteins: Form and function. J. Biol. Chem. 2014, 289, 17406-17415. [CrossRef] [PubMed]

9. Prokopowicz, Z.; Marcinkiewicz, J.; Katz, D.R.; Chain, B.M. Neutrophil myeloperoxidase: Soldier and statesman. Arch. Immunol. Ther. Exp. (Warsz) 2012, 60, 43-54. [CrossRef] [PubMed]

10. Arnhold, J.; Furtmüller, P.G.; Regelsberger, G.; Obinger, C. Redox properties of the couple compound I/native enzyme of myeloperoxidase and eosinophil peroxidase. Eur. J. Biochem. 2001, 268, 5142-5148. [CrossRef] [PubMed]

11. Klebanoff, S.J.; Kettle, A.J.; Rosen, H.; Winterbourn, C.C.; Nauseef, W.M. Myeloperoxidase: A front-line defender against phagocytosed microorganisms. J. Leukoc. Biol. 2013, 93, 185-198. [CrossRef] [PubMed]

12. Furtmüller, P.G.; Burner, U.; Regelsberger, G.; Obinger, C. Spectral and kinetic studies on the formation of eosinophil peroxidase compound I and its reaction with halides and thiocyanate. Biochemistry 2000, 39, 15578-15584. [CrossRef] [PubMed]

13. Augusto, O.; Miyamoto, S. Oxygen radicals and related species. In Principles of free radical biomedicine; Pantopoulos, K., Schipper, H.M., Eds.; Nova Science Publishers Inc.: New York, NY, USA, 2011; pp. $19-42$.

14. Rayner, B.S.; Love, D.T.; Hawkins, C.L. Comparative reactivity of myeloperoxidase-derived oxidants with mammalian cells. Free Radic. Biol. Med. 2014, 71, 240-255. [CrossRef] [PubMed]

15. Ximenes, V.F.; Morgon, N.H.; de Souza, A.R. Hypobromous acid, a powerful endogenous electrophile: Experimental and theoretical studies. J. Inorg. Biochem. 2015, 146, 61-68. [CrossRef] [PubMed]

16. Sivey, J.D.; Arey, J.S.; Tentscher, P.R.; Roberts, A.L. Reactivity of $\mathrm{BrCl}, \mathrm{Br}_{2}, \mathrm{BrOCl}, \mathrm{Br}_{2} \mathrm{O}$, and $\mathrm{HOBr}$ toward dimethenamid in solutions of bromide + aqueous free chlorine. Environ. Sci. Technol. 2013, 47, 1330-1338. [CrossRef] [PubMed]

17. Yazdanbakhsh, M.; Eckmann, C.M.; Roos, D. Killing of schistosomula by taurine chloramine and taurine bromamine. Am. J. Trop. Med. Hyg. 1987, 37, 106-110. [PubMed]

18. Weiss, S.J.; Test, S.T.; Eckmann, C.M.; Roos, D.; Regiani, S. Brominating oxidants generated by human eosinophils. Science 1986, 234, 200-203. [CrossRef] [PubMed]

19. Simonart, T. Newer approaches to the treatment of acne vulgaris. Am. J. Clin. Dermatol. 2012, 13, 357-364. [CrossRef] [PubMed] 
20. Marcinkiewicz, J.; Biedroń, R.; Białecka, A.; Kasprowicz, A.; Mak, M.; Targosz, M. Susceptibility of Propionibacterium acnes and Staphylococcus epidermidis to killing by MPO-halide system products. Implication for taurine bromamine as a new candidate for topical therapy in treating acne vulgaris. Arch. Immunol. Ther. Exp. (Warsz) 2006, 54, 61-68. [CrossRef] [PubMed]

21. Marcinkiewicz, J.; Strus, M.; Walczewska, M.; Machul, A.; Mikołajczyk, D. Influence of taurine haloamines (TauCl and TauBr) on the development of Pseudomonas aeruginosa biofilm: A preliminary study. Adv. Exp. Med. Biol. 2013, 775, 269-283. [PubMed]

22. Strus, M.; Walczewska, M.; Machul, A.; Mikołajczyk, D.; Marcinkiewicz, J. Taurine Haloamines and Biofilm. Part I: Antimicrobial Activity of Taurine Bromamine and Chlorhexidine Against Biofilm Forming Pseudomonas aeruginosa. J. Adv. Exp. Med. Biol. 2015, 803, 121-132.

23. Gottardi, W.; Klotz, S.; Nagl, M. Superior bactericidal activity of N-bromine compounds compared to their N-chlorine analogues can be reversed under protein load. J. Appl. Microbiol. 2014, 116, 1427-1437. [CrossRef] [PubMed]

24. Marcinkiewicz, J.; Walczewska, M.; Olszanecki, R.; Bobek, M.; Biedroń, R.; Dulak, J.; Józkowicz, A.; Kontny, E.; Maślinski, W. Taurine haloamines and heme oxygenase-1 cooperate in the regulation of inflammation and attenuation of oxidative stress. Adv. Exp. Med. Biol. 2009, 643, 439-450. [PubMed]

25. Tokunaga, S.; Kanayama, A.; Miyamoto, Y. Modification of IkappaBalpha by taurine bromamine inhibits tumor necrosis factor alpha-induced NF-kappaB activation. Inflamm. Res. 2007, 56, 479-486. [CrossRef] [PubMed]

26. Kim, C.; Cha, Y.N. Taurine chloramine produced from taurine under inflammation provides anti-inflammatory and cytoprotective effects. Amino Acids 2014, 46, 89-100. [CrossRef] [PubMed]

27. Peskin, A.V.; Winterbourn, C.C. Taurine chloramine is more selective than hypochlorous acid at targeting critical cysteines and inactivating creatine kinase and glyceraldehyde-3-phosphate dehydrogenase. Free Radic. Biol. Med. 2006, 40, 45-53. [CrossRef] [PubMed]

28. Sun Jang, J.; Piao, S.; Cha, Y.N.; Kim, C. Taurine Chloramine Activates Nrf2, Increases HO-1 Expression and Protects Cells from Death Caused by Hydrogen Peroxide. J. Clin. Biochem. Nutr. 2009, 45, 37-43. [CrossRef] [PubMed]

29. Kim, K.S.; Ji, H.I.; Chung, H.; Kim, C.; Lee, S.H.; Lee, Y.A.; Yang, H.I.; Yoo, M.C.; Hong, S.J. Taurine chloramine modulates the expression of adipokines through inhibition of the STAT-3 signaling pathway in differentiated human adipocytes. Amino Acids 2013, 45, 1415-1422. [CrossRef] [PubMed]

30. Kim, C.; Kang, I.S. Taurine Chloramine, a Taurine Metabolite from Activated Neutrophils, Inhibits Osteoclastogenesis by Suppressing NFATc1 Expression. Adv. Exp. Med. Biol. 2015, 803, 99-107. [PubMed]

31. Gottardi, W.; Nagl, M. Chemical properties of N-chlorotaurine sodium, a key compound in the human defence system. Arch. Pharm. (Weinheim) 2002, 335, 411-421. [CrossRef]

32. Gottardi, W.; Debabov, D.; Nagl, M. N-chloramines, a promising class of well-tolerated topical anti-infectives. Antimicrob. Agents Chemother. 2013, 57, 1107-1114. [CrossRef] [PubMed]

33. Thomas, E.L.; Bozeman, P.M.; Jefferson, M.M.; King, C.C. Oxidation of bromide by the human leukocyte enzymes myeloperoxidase eosinophil peroxidase. Formation of bromamines. J. Biol. Chem. 1995, 270, 2906-2913. [PubMed]

34. Petrônio, M.S.; Ximenes, V.F. Inhibition of lysozyme by taurine dibromamine. Protein. Pept. Lett. 2013, 20, 1232-1237. [CrossRef] [PubMed]

35. Carvalho, L.C.; Estevão, M.S.; Ferreira, L.M.; Fernandes, E.; Marques, M.M. A new insight on the hypochlorous acid scavenging mechanism of tryptamine and tryptophan derivatives. Bioorg. Med. Chem. Lett. 2010, 20, 6475-6478. [CrossRef] [PubMed]

36. Gulçin, I. Measurement of antioxidant ability of melatonin and serotonin by the DMPD and CUPRAC methods as trolox equivalent. J. Enzyme Inhib. Med. Chem. 2008, 23, 871-876. [CrossRef] [PubMed]

37. Tan, D.X.; Manchester, L.C.; Esteban-Zubero, E.; Zhou, Z.; Reiter, R.J. Melatonin as a Potent and Inducible Endogenous Antioxidant: Synthesis and Metabolism. Molecules 2015, 20, 18886-18906. [CrossRef] [PubMed]

38. Jantschko, W.; Furtmüller, P.G.; Allegra, M.; Livrea, M.A.; Jakopitsch, C.; Regelsberger, G.; Obinger, C. Redox intermediates of plant and mammalian peroxidases: A comparative transient-kinetic study of their reactivity toward indole derivatives. Arch. Biochem. Biophys. 2002, 398, 12-22. [CrossRef] [PubMed]

39. Graciani, F.S.; Ximenes, V.F. Investigation of human albumin-induced circular dichroism in dansylglycine. PLoS ONE 2013, 8, e76849. [CrossRef] [PubMed] 
40. Ximenes, V.F.; da Fonseca, L.M.; de Almeida, A.C. Taurine bromamine: A potent oxidant of tryptophan residues in albumin. Arch. Biochem. Biophys. 2011, 507, 315-322. [CrossRef] [PubMed]

41. Petrônio, M.S.; Ximenes, V.F. Light emission from tryptophan oxidation by hypobromous acid. Luminescence 2013, 28, 853-859. [CrossRef] [PubMed]

42. Kasai, S.; Horie, T.; Mizuma, T.; Awazu, S. Fluorescence energy transfer study of the relationship between the lone tryptophan residue and drug binding sites in human serum albumin. J. Pharm. Sci. 1987, 76, 387-392. [CrossRef] [PubMed]

43. Lakowicz, J.R. Principles of Fluorescence Spectroscopy, 3rd ed.; Springer US: New York, NY, USA, 2006; pp. $45-135$.

44. Kettle, A.J.; Albrett, A.M.; Chapman, A.L.; Dickerhof, N.; Forbes, L.V.; Khalilova, I.; Turner, R. Measuring chlorine bleach in biology and medicine. Biochim. Biophys. Acta 2014, 1840, 781-793. [CrossRef] [PubMed]

45. Ximenes, V.F.; Padovan, C.Z.; Carvalho, D.A.; Fernandes, J.R. Oxidation of melatonin by taurine chloramine. J. Pineal Res. 2010, 49, 115-122. [CrossRef] [PubMed]

46. Kanofsky, R.; Hoogland, H.; Wever, R.; Weiss, S.J. Singlet oxygen production by human eosinophils. J. Biol. Chem. 1988, 263, 9692-9696. [PubMed]

47. Kładna, A.; Aboul-Enein, H.Y.; Kruk, I. Enhancing effect of melatonin on chemiluminescence accompanying decomposition of hydrogen peroxide in the presence of copper. Free Radic. Biol. Med. 2003, 34, 1544-1554. [CrossRef]

48. De Almeida, E.A.; Martinez, G.R.; Klitzke, C.F.; de Medeiros, M.H.; Di Mascio, P. Oxidation of melatonin by singlet molecular oxygen (O2(1deltag)) produces $N_{1}$-acetyl-N2-formyl-5-methoxykynurenine. J. Pineal Res. 2003, 35, 131-137. [CrossRef] [PubMed]

49. Spalteholz, H.; Panasenko, O.M.; Arnhold, J. Formation of reactive halide species by myeloperoxidase and eosinophil peroxidase. Arch. Biochem. Biophys. 2006, 445, 225-324. [CrossRef] [PubMed]

50. Pitt, A.R.; Spickett, C.M. Mass spectrometric analysis of $\mathrm{HOCl}^{-}$and free-radical-induced damage to lipids and proteins. Biochem. Soc. Trans. 2008, 36, 1077-1082. [CrossRef] [PubMed]

51. Stanley, N.R.; Pattison, D.I.; Hawkins, C.L. Ability of hypochlorous acid and N-chloramines to chlorinate DNA and its constituents. Chem. Res. Toxicol. 2010, 23, 1293-1302. [CrossRef] [PubMed]

52. Sassa, A.; Kamoshita, N.; Matsuda, T.; Ishii, Y.; Kuraoka, I.; Nohmi, T.; Ohta, T.; Honma, M.; Yasui, M. Miscoding properties of 8-chloro-2'-deoxyguanosine, a hypochlorous acid-induced DNA adduct, catalysed by human DNA polymerases. Mutagenesis 2013, 28, 81-88. [CrossRef] [PubMed]

53. Sassa, A.; Ohta, T.; Nohmi, T.; Honma, M.; Yasui, M. Mutational specificities of brominated DNA adducts catalyzed by human DNA polymerases. J. Mol. Biol. 2011, 406, 679-686. [CrossRef] [PubMed]

54. Kettle, A.J.; Winterbourn, C.C. Assays for the Chlorination Activity of Myeloperoxidase. Methods Enzymol. 1994, 233, 502-512. [PubMed]

(C) 2016 by the authors; licensee MDPI, Basel, Switzerland. This article is an open access article distributed under the terms and conditions of the Creative Commons Attribution (CC-BY) license (http:/ / creativecommons.org/licenses/by/4.0/). 